\title{
Fifteenth Census of Seabird Populations in the Sanctuaries of the North Shore of the Gulf of St. Lawrence, 1998-1999
}

\author{
JeAn-François Rail and Gilles Chapdelaine \\ Canadian Wildlife Service, P. O. Box 10100, Ste-Foy, Québec G1V 4H5 Canada
}

Rail, Jean-François, and Gilles Chapdelaine. 2004. Fifteenth census of seabird populations in the sanctuaries of the North Shore of the Gulf of St. Lawrence, 1998-1999. Canadian Field-Naturalist 118(2): 256-263.

For the first time since the tradition began in 1925, the quinquennial census of seabirds in the Migratory Bird Sanctuaries of the North Shore of the Gulf of St. Lawrence was divided between two years in 1998-1999. Trends between 1993 and 1998-1999 were variable across species and sanctuaries. In particular, following the large decreases in both species noted in 1993, the 1998-1999 survey showed that Black-legged Kittiwakes had declined further, while the number of Herring Gulls had stabilized. Alcids were all doing well except for the Atlantic Puffin which showed severe yet unexplained drops at all major colonies. Law enforcement efforts appear reflected in seabird population trends, as well-patrolled sanctuaries such as St. Mary's Islands seem to do well, whereas many species at the Baie des Loups and Île à la Brume sanctuaries are far from their historical levels. In addition to a better law enforcement program, research is needed in order to identify other conservation problems that some species may be facing.

Pour la première fois depuis 1925 , l'inventaire quinquennal des oiseaux marins des refuges d'oiseaux migrateurs de la CôteNord du Golfe Saint-Laurent fut mené sur deux ans, soit en 1998 et 1999. Les tendances des populations entre 1993 et 1998 1999 étaient variables selon l'espèce et le refuge. En particulier, suite à une décroissance notée chez les deux espèces en 1993 , l'inventaire de 1998-1999 a démontré que la Mouette tridactyle avait encore diminué, tandis que le nombre de Goélands argentés s'était stabilisé. Les populations d'Alcidés ont toutes semblé en bonne santé sauf celle du Macareux moine dont les colonies importantes ont diminué de façon sévère et inexpliquée. Les efforts de protection par l'application de la loi se reflètent visiblement dans les tendances des populations d'oiseaux de mer, puisque les refuges les mieux surveillés comme celui des Îles Sainte-Marie vont bien, alors que plusieurs espèces aux refuges de Baie des Loups et de l'île à la Brume sont loin de leurs niveaux historiques. En plus d'un meilleur programme d'application de la loi, la recherche est nécessaire pour identifier les autres problèmes de conservation auxquels certaines espèces font face.

Key Words: Seabirds, populations, sanctuaries, Gulf of St. Lawrence, Atlantic Puffin, larids, alcids.

Apart from its major use in providing updated information on seabird numbers and distribution throughout the migratory bird sanctuaries on the North Shore of the Gulf of St. Lawrence (Figure 1), another major application of the results of this traditional survey is in identifying trends. Follow-up censuses have been carried out fairly regularly since the first census in 1925 (Lewis 1925, 1931, 1937, 1942; Hewitt 1950; Tener 1951; Lemieux 1956; Moisan 1962; Moisan and Fyfe 1967; Nettleship and Lock 1973; Chapdelaine 1980, 1995; Chapdelaine and Brousseau 1984, 1991), providing the trends over a period of approximately 75 years, including the present survey. This survey also provides one of the ways we monitor the broader marine environment. In effect, these wide-ranging birds are acting as our sampling agents. As human impact on the seas increases, whether directly by exploitation of resources or marine pollution, or less directly by factors such as global warming, early indications of changes are vital. Clearly any changes in the size of seabird breeding colonies are of major importance to conservationists to orient any concrete action to be taken or to seabird biologists to learn more about the regulation of seabird numbers and the wide range of factors known to influence the birds.
This article presents the current status of the 15 marine bird species breeding in the sanctuaries in 19981999, and compares them with those of the 1993 census. Scientific names are given in Table 1.

\section{Methods}

The census of seabirds in the sanctuaries of the North Shore of the Gulf of St. Lawrence was conducted over two years. All of the technical details of this census (methods, estimates calculations, mapping of the colonies, weather conditions) are discussed in Rail and Chapdelaine (2002) and summarized below for each family of birds.

GAVIIDS - We counted all Red-throated Loon nests by systematically walking around the ponds on the islands of each sanctuary. In a few exceptional cases we noted the presence of adults instead of landing on the island.

HYDROBATIDS - We conducted a systematic count of active burrows. A burrow was considered active if we were able to reach an adult inside, or detect signs of recent occupation (soil freshly excavated or oily odour characteristic of petrels at the entrance of the burrow).

ANATIDS - On Corossol Island, we used a system of quadrats from which we extrapolated and average density (nests/ha) for the entire area deemed suitable 


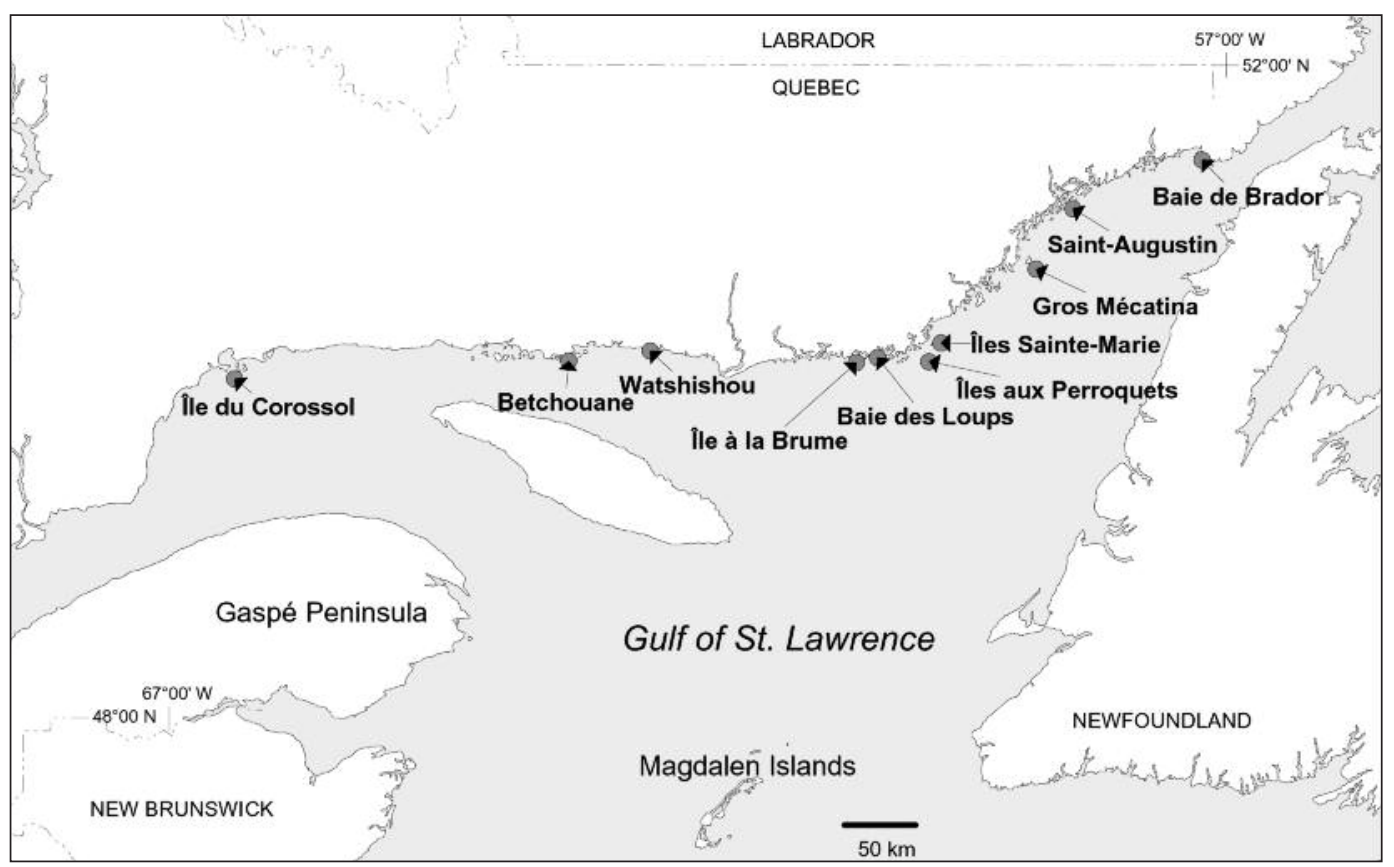

FIGURE 1. Location of the sanctuaries of the North Shore of the Gulf of St. Lawrence.

for Common Eiders (Chapdelaine 1978*). In the Betchouane Bird Sanctuary, we conducted a systematic nest count on Calculot Island, and (as in preceding censuses) used a system of line-transects of varying length on Innu Island (see Caughley 1977). In sanctuaries featuring many islands (e.g., Watshishou, île à la Brume, Baie des Loups), we counted all the nests on at least $27 \%$ of the land area and extrapolated an average density over the entire area of all the islands. On the Îles aux Perroquets and Îles Sainte-Marie sanctuaries, extrapolation was done after systematic counts were made on most large islands, covering $57 \%$ and $98 \%$ of total land area, respectively (but see Rail and Chapdelaine 2002 for details).

PHALACROCORACIDS - Systematic counts of all Great and Double-crested Cormorant nests were carried out. At the Corossol Island colony, Double-crested Cormorant nests in treetops were counted from an elevated lookout point.

LARIDS - In the large Herring Gull colony of Corossol Island, we sampled sub-colonies where the number of nests $(\mathrm{Np})$ and the number of adults $(\mathrm{Ni})$ were determined. Then, using the factor $\mathrm{k}(\mathrm{k}=\mathrm{Np} / \mathrm{Ni})$, we estimated the number of pairs in sectors where we counted only the number of adults present. In the Betchouane Sanctuary, all gull nests were counted systematically, and were attributed to Herring and Great Black-backed gulls according to the observed proportions of adults of both species. In the other sanctu- aries all larids were censused with a combination of nest counts and adult counts. Proportions of Arctic and Common terns in mixed tern colonies were not always determined, so the results for the two species are combined in Table 1. All Black-legged Kittiwake nests attended by adults were counted.

ALCIDS - We carried out systematic counts of eggs and active burrows in colonies of Atlantic Puffins, Razorbills and Common Murres that could be accessed with minimal disturbance. Elsewhere we counted individuals at the colony and on adjacent waters from a distance. All colonies with large numbers of Common Murres were carefully avoided because of their sensitivity to disturbance. In particular, at the Îles SainteMarie Sanctuary, where $87 \%$ of breeding Common Murres on the North Shore are found, $98 \%$ of the population estimate for the Common Murre results from adult counts. For Atlantic Puffins nesting on the Blacklands Island in the Baie des Loups Sanctuary, we used the factor $\mathrm{k}$ method described above for larids. On Île aux Perroquets in the Baie de Brador Sanctuary, we used evenly spaced grids and line transects to delimit the area of both the puffin and Razorbill colonies, evaluate mean nest densities, and then extrapolated the populations (see Nettleship 1973*; Chapdelaine 1978*). The Black Guillemot population was estimated from adult bird counts around the islands, although exceptionally we recorded a pair when a nest was found with no adult in sight. 


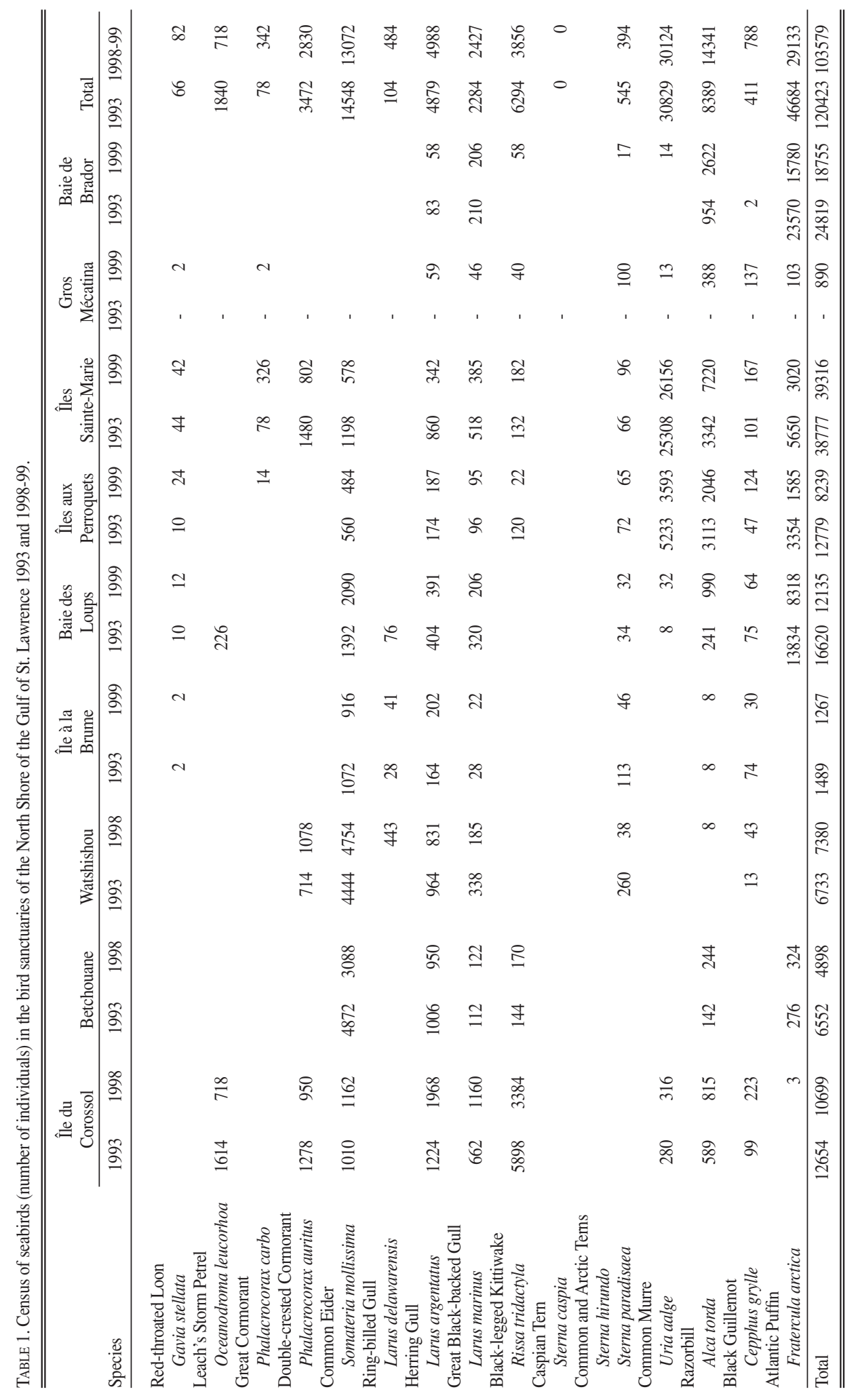


TABLE 2. Changes in the numbers of seabirds in sanctuaries on the North Shore of the Gulf of St Lawrence, Québec, 1988 to 1998-1999.

\begin{tabular}{|c|c|c|c|c|c|}
\hline \multirow[b]{2}{*}{ Species } & \multicolumn{3}{|c|}{ Years of survey } & \multicolumn{2}{|c|}{$\begin{array}{l}\text { Compound annual growth* } \\
\text { rate by period }\end{array}$} \\
\hline & 1988 & 1993 & 1998-1999 & $1988-1993$ & $1993-1998 * *$ \\
\hline Red-throated Loon & 76 & 66 & 80 & $-2.82 \%$ & $3.21 \%$ \\
\hline Leach's Storm-Petrel & 1744 & 1840 & 718 & $1.07 \%$ & $-18.78 \%$ \\
\hline Great Cormorant & 86 & 78 & 340 & $-1.95 \%$ & $24.54 \%$ \\
\hline Double-crested Cormorant & 4558 & 3472 & 2830 & $-5.44 \%$ & $-3.49 \%$ \\
\hline Common Eider & 8536 & 14548 & 13072 & $10.66 \%$ & $-2.10 \%$ \\
\hline Ring-billed Gull & 288 & 104 & 484 & $-20.37 \%$ & $31.04 \%$ \\
\hline Herring Gull & 16195 & 4879 & 4929 & $-24.00 \%$ & $0.49 \%$ \\
\hline Great Black-backed Gull & 1883 & 2284 & 2381 & $3.86 \%$ & $1.15 \%$ \\
\hline Black-legged Kittiwake & 8536 & 6294 & 3816 & $-6.09 \%$ & $-10.02 \%$ \\
\hline Caspian Tern & 15 & 0 & 0 & $-100.00 \%$ & - \\
\hline Common and Arctic Terns & 1350 & 545 & 294 & $-18.14 \%$ & $-12.03 \%$ \\
\hline Common Murre & 26049 & 30829 & 30111 & $3.37 \%$ & $-0.39 \%$ \\
\hline Razorbill & 7036 & 8389 & 13953 & $3.52 \%$ & $8.58 \%$ \\
\hline Black Guillemot & 521 & 411 & 651 & $-4.74 \%$ & $8.70 \%$ \\
\hline Atlantic Puffin & 35142 & 46684 & 29030 & $5.68 \%$ & $-7.92 \%$ \\
\hline
\end{tabular}

$*_{r}=\frac{\log _{\mathrm{e}} \mathrm{N}(\mathrm{t})-\log _{\mathrm{e}} \mathrm{N}(\mathrm{o})}{\mathrm{t}} 100 \%$

** Populations in sanctuaries censused in 1999 were back-calculated to 1998 to get the compound annual growth rate for all North Shore sanctuaries after 5 years

\section{Results}

In the eight sanctuaries censused in 1993 and 19981999 (Gros Mecatina excluded), the total number of birds had decreased by $15 \%$ or 17734 individuals (see Table 1 for details). This is mostly due to the dramatic 38\% decline of the Atlantic Puffin (-17 654 individuals), which was by far the most abundant seabird in the North Shore sanctuaries in 1993 (but was outnumbered by the Common Murre in 1999). Leach's Storm-Petrels, Black-legged Kittiwakes and Common and Arctic Terns also declined at a very rapid rate between 1993 and 1998-1999 (Table 2). Double-crested Cormorants numbers also diminished. The Razorbill is the only abundant species showing a large increase, with the 1998-1999 population estimate exceeding by 5564 individuals the result of $1993(+66 \%)$. This species has made a spectacular comeback since 1972, when less than 3000 individuals were recorded in the sanctuaries (compared to 14341 in 1998-1999). The small populations of Great Cormorants, Ring-billed Gulls and Black Guillemots also grew rapidly between 1993 and 19981999, as did Red-throated Loons but more slowly. In four species, numbers appeared rather stabilized, the Common Eider and Herring Gull after having showed very sharp trends between 1988 and 1993 (annual growth rates of $+11 \%$ and $-24 \%$, respectively), the Great Black-backed Gull and Common Murre following less striking but significant rises (annual growth rate of +3.9 and $+3.4 \%$, respectively). Finally, no Caspian Terns were found for the second quinquennial census in a row.

We visited the Corossol Island Sanctuary on 30 and 31 May 1998. Major increases in large gulls (Herring and Great Black-backed gulls) were noted. Populations of alcids also expanded, and in particular the number of Black Guillemots more than doubled compared to 1993. Puffins were recorded for the first time during quinquennial censuses, bringing up to 10 the number of seabird species breeding there. The Common Eider was also more abundant. On the other hand, the colony of Leach's Storm-Petrels was reduced to less than half between 1993 and 1998, and Black-legged Kittiwakes also declined quite rapidly. Double-crested Cormorants were down $25 \%$, and colony localization had seemed to change a bit, possibly prompted by forest decay caused by their long-term occupation (nests are in treetops of conifers) in some areas.

On 2 and 3 June 1998, we visited the Betchouane Bird Sanctuary. The most important change in the seabird community was the $36 \%$ decrease in Common Eider, by far the most abundant bird there. The Razorbill apparently continued its spectacular comeback, with a 72\% population increase between 1993 and 1998. Herring Gulls, Great Black-backed Gulls, Blacklegged Kittiwakes and Atlantic Puffins were almost stable or slightly increasing. 
After a tremendous population explosion following 1982, the population growth of the Common Eider in Watshishou appeared to have slowed down considerably between 1993 and 1998. The Black Guillemot population increased threefold during the same period. Double-crested Cormorant and Great Black-backed Gull numbers showed opposite trends; the former species underwent a $50 \%$ increase whereas the latter was reduced by half. Herring Gull population size appeared slightly reduced compared to 1993, but the 1998 result was by far the highest for the species in Watshishou, except for 1993. The 1998 survey confirmed a catastrophic $(-96 \%)$ and inexplicable decline of terns in Watshishou since 1988. In the past, this sanctuary, consisting of more than 200 islands, always had a fair number of terns (range 128 - 1490 individuals), and was the most important sanctuary on the North Shore in that regard. In 1998, however, despite better coverage (more islands were visited than in previous censuses), we found only 19 breeding pairs distributed in 5 very small colonies. The Watshishou Bird Sanctuary was visited on 6,7 and 8 June 1998.

The following year (in 1999), seabirds were censused on 14 June at the Île à la Brume Sanctuary. The Common Eider had decreased slightly since 1993, but was still relatively abundant. Population trends were up for Herring and Ring-billed gulls; however numbers of these two species are rather small and tended to vary a lot in the past. The number of Great Black-backed Gulls dropped further between 1993 and 1999, reaching its lowest level ever in 1999. Terns declined sharply during the same period, and in fact since 1988 their population trends at the Île à la Brume $(-84 \%)$ and Watshishou sanctuaries are similar. Status of the very small populations of Red-throated Loon and Razorbill are still precarious, as their numbers remained stable between 1993 and 1999 at two and eight individuals, respectively. Finally, no Caspian Terns were found for the second quinquennial census in a row at Île à la Brume, the only traditional breeding site for this species in the Province of Québec.

We visited the Baie des Loups Bird Sanctuary on 18 June. The most abundant bird there, the Atlantic Puffin, had declined by $40 \%$ since 1993 . The Great Black-backed Gull population also decreased noticeably (36\%). Breeding Leach's Storm-Petrels apparently deserted the sanctuary, which leaves the Corossol Island Sanctuary as the only active breeding site of that species on the North Shore, and maybe in the whole province. On the brighter side, the Common Eider population increased by $50 \%$. Also, the Common Murre and the Razorbill, once abundant in the sanctuary but which had declined steadily up to the very low and worrying levels observed in 1993, bounced back and increased threefold between 1993 and 1999. Redthroated Loon, Herring Gull, terns, and Black Guillemot numbers remained fairly stable.
The Îles aux Perroquets Bird Sanctuary was visited on 11 and 21 June 1999. The population of Atlantic Puffin showed a similar drop $(-53 \%)$ as in the other large colonies on the North Shore. In contrast to the general upward trend observed in these species at the other sanctuaries, a decrease in Common Murres and Razorbills was noted at the Îles aux Perroquets Bird Sanctuary in 1999. The number of Common Eiders declined only slightly. Except for the Black-legged Kittiwakes whose population collapsed (-82\%) between 1993 and 1999, numbers of larids were quite stable. With only 11 nests found in 1999, the kittiwake may well disappear as a breeding species at the Îles aux Perroquets in the future. On the positive side, the two smallest seabird populations breeding in the sanctuary in 1993, those of the Red-throated Loon and Black Guillemot, both showed large increases (140\% and $164 \%$, respectively). Also worthy of notice is the addition of the Great Cormorant as a breeding species in the sanctuary.

The Îles Sainte-Marie Bird Sanctuary (visited on $10,11,13,17$ and 19 June) was again found to have the highest seabird diversity (12 breeding species) and abundance (total of 39316 individuals). Common Murres represented two-thirds of the seabird population with an estimated 26156 breeding birds. The number of murres appeared quite stable between 1993 and 1999, after the spectacular and steady recovery of the species following 1972 (when only 4120 birds were counted). Razorbills show the same long-term trend as murres, but were still going up in 1999 (116\% rise compared to 1993). The Great Cormorant colony expanded unexpectedly $(+318 \%)$ to become the largest of this species on the North Shore. Increases were noted in Black-legged Kittiwakes, Black Guillemots and terns as well. Numbers of Double-crested Cormorants, Common Eiders, and Atlantic Puffins were reduced roughly by half. Herring Gulls were again found to be declining very sharply, whereas Great Black-backed Gulls showed a moderate decrease. Finally, the number of Red-throated Loons in 1999 was only one pair short of the highest counts which were recorded on the two preceding censuses.

A little farther to the east, a few small offshore islands constitute the Gros Mécatina Bird Sanctuary, which was created in 1996. On 23 June 1999, the sanctuary was included for the first time in a quinquennial census. Species diversity was impressive for such a small sanctuary, as nine seabird species were found breeding. Numbers of each species were low though, and the most abundant species was the Razorbill with 388 birds observed. According to naturalists such as Coues (1862), these islands were once inhabited by tens of thousands of Common Murres, so the sanctuary has definite potential for seabird conservation if it is well protected. 
The Baie de Brador Bird Sanctuary is well-known for its colonies of Atlantic Puffin and Razorbill. On 28 and 29 June 1999 however, we were quite surprised to discover the addition of Black-legged Kittiwakes and terns breeding there for the first time, as well as Common Murres which had not bred there since 1965. Herring Gulls and Great Black-backed Gulls seemed well established as breeders for the second census in a row (they were present in very small numbers or absent prior to 1993). Also, as in most other sanctuaries, Razorbill numbers grew very fast between 1993 and 1999 (+175\%). Nevertheless, all these results were darkened by the finding that Atlantic Puffins had declined by a third since 1993 , when the population seemed on its way to get back to historic levels. Because it has always been the stronghold of puffins in our province, the Baie de Brador Bird Sanctuary plays a leading role in the conservation of the species in Québec.

\section{Discussion}

Total number of seabirds recorded in 1998-1999 in the North Shore Bird Sanctuaries dropped 15\% (or 17734 birds, Gros Mécatina excluded). But most of this decrease could be attributed to the Atlantic Puffin whose $38 \%$ decline represent a loss of 17551 birds. Population trends in other species were variable, as four species increased rapidly, four species decreased at a fast rate, and the others showed more stable or moderate trends. Numbers of Razorbills and Black Guillemots increased at a very rapid rate in almost every sanctuary (where they are present). The only Great Cormorant colony recorded during the 1993 census was found at the Îles Sainte-Marie Bird Sanctuary; by 1999, that colony had grown so much that immigration must be partly involved. Also, three new colonies of this species were found elsewhere in the sanctuaries in 1999. The Ring-billed Gull is the last seabird species which increased at a very fast rate since 1993 . However, this species is poorly represented in the North Shore Bird Sanctuaries, where their numbers always fluctuated widely in the past. Instead of suggesting a real population trend, our results may rather reflect colony displacements as the species exhibits poor site fidelity on the North Shore.

The Atlantic Puffin was not the only species showing a sharp decline between the last two censuses of the North Shore sanctuaries. The case of the Leach's Storm-Petrel is equally worrying; the species was found breeding in four sanctuaries in 1988, but in 19981999 only the Corossol Island colony was still active, and its number of nests was reduced to less than half compared to 1993. Moreover, this may be the only Leach's Storm-Petrel colony left in the whole province. Thus the status of the species appears precarious in Québec. The Black-legged Kittiwake was found breeding in six sanctuaries in 1998-1999, whereas in the past it had been breeding in no more than four sanctuaries.
However, over $90 \%$ of the kittiwakes in the sanctuaries are concentrated at the Corossol Island colony, where a 39\% drop was observed between 1993 and 1998. In fact the colony decreased by $55 \%$ since 1988 and the trend was even faster in the last five years. Observations made on diet and breeding success of larids at Corossol Island in 1996-1998 showed that kittiwake breeding success was severely affected by Herring Gull predation on large chicks, especially when capelin appeared less available. The poor kittiwake productivity measured in 1997-1998 (0.60 and 0.27 young fledged per pair, respectively) means that recruitment is likely not enough to compensate for natural mortality, so that further decline of the colony is expected. Terns, after the fashion of Ring-billed Gulls, are poorly represented in the sanctuaries and their population trends partly reflect the unpredictability of their breeding activities. However, their numbers dropped severely for a second quinquennial census in a row, resulting in a $80 \%$ decline since 1988 . The case of the Watshishou Bird Sanctuary, which has always been the most important for terns, is particularly intriguing as that tern population reached an unprecedented low level in 1998.

Among species with near-stable population trends between 1993 and 1998-1999 are the Common Eider and the Common Murre, two species whose numbers finally appeared to level off after spectacular increases were noted in each of the four preceding censuses. Herring Gull population trends on the North Shore (and especially at Corossol Island) have been correlated with cod fishery, an industry that provided significant amounts of fish offal available to gulls (Chapdelaine and Rail 1997). After a boom in the early 1980s, cod fishery and Herring Gull populations collapsed concurrently in the late 1980s-early 1990s. But in 19981999 it seemed that after a drastic $(-78 \%)$ decline between 1988 and 1993, the Herring Gull population was stabilized, perhaps to a more "natural" level. The number of Red-throated Loons increased only slightly between the last two surveys, yet the 1998-1999 total (82 individuals) is the highest ever recorded in the sanctuaries. The Double-crested Cormorant population declined but only at a slow rate after 1993, and in 19981999 the total population estimate for the sanctuaries was still the third highest since 1925 . The steady rise of Great Black-backed Gull numbers continued to slow down to be nearly stable between 1993 and 1998. Finally, the Caspian Tern did not breed in 1993 and 1999 at the Île à la Brume Sanctuary, where it consistently nested between 1925 and 1988. The more time passes by, the more unlikely this species will be back, unless appropriate measures are taken to prevent disturbance of the only breeding site of Caspian Terns in Québec.

While some population trends varied regionally, others suggest large-scale factors are involved. In particular, Black-legged Kittiwake and Herring Gull declines since the end of the 1980 s are reported not only 
in North Shore sanctuaries, but also at all large colonies around the Gaspé Peninsula and at the Magdalen Islands (Chapdelaine et al. 2003*). Atlantic Puffin numbers dropped at all major North Shore concentrations between 1993 and 1999. On the other hand, Razorbill colonies continued to expand everywhere in the Gulf and in the Estuary (Chapdelaine et al. 2001), and the small populations of Great Cormorant on the North Shore and around the Gaspé Peninsula grew significantly since 1988-1990. So far we have presented some evidence that the Herring Gull population had been influenced by cod fishery activities (Chapdelaine and Rail 1997), and that an abundance of small fish such as sandlance (Ammodytes sp.) and Capelin (Mallotus villosus) had a positive effect on alcid breeding performance and populations (Chapdelaine and Brousseau 1991, 1996; Rail et al. 1996). But most population trends are left unexplained.

The fact that law enforcement efforts have not been distributed uniformly across sanctuaries probably explains why, in sanctuaries such as île à la Brume and Baie des Loups, many seabird populations are at low levels and signs of disturbance are omnipresent. Conversely, the well-patrolled Îles Sainte-Marie Bird Sanctuary appears in good shape. Seabird conservation in North Shore bird sanctuaries face many challenges: ecotourism, disturbance, poaching, episodic fox invasion in the sanctuaries, seabird bycatch in nearby fishing nets, along with ecological factors at all scales. This stresses the need to maintain and improve law enforcement and public educational programs, and highlights the importance of research to tackle the factors responsible for the observed seabird population trends.

\section{Acknowledgments}

Many thanks to all those who contributed to this. Fieldwork was carried out with the help of our colleagues Pierre Brousseau and Jocelyn Thibault, Gilles Falardeau with his assistants Linda Burr and Daniel Daigneault, and Canadian Wildlife Service wardens Freddy Strickland and Wilson Evans. Members of Parks Canada in Mingan and assisting volunteers also gave us a big hand, as well as Andrew Rowsell from Fisheries and Oceans Canada in Blanc-Sablon. Finally, our special thaughts go to M. Gallienne and his family for their hospitality on Corossol Island.

\section{Documents Cited (marked $*$ in text)}

Chapdelaine, G. 1978. Onzième inventaire des oiseaux coloniaux des refuges de la côte nord du Golfe Saint-Laurent et révision globale de la fluctuation des populations depuis 1925 jusqu'à 1977. Service canadien de la faune, région du Québec, Environnement Canada, Sainte-Foy, 166 pages.

Chapdelaine, G., P. Brousseau, and J.-F. Rail. 2003. Banque informatisée des oiseaux marins du Québec (BIOMQ). Database. Last update 12 March 2003. Environment Canada, Canadian Wildlife Service, Québec Region.

Nettleship, D. N. 1973. Census of seabirds in the sanctuaries of the North Shore of the Gulf of St. Lawrence, summer
1972. Studies on northern seabirds No 20. Canadian Wildlife Service Report, Ottawa, 160 pages.

\section{Literature Cited}

Caughley, G. 1977. Analysis of vertebrate populations. John Wiley and Sons, London.

Chapdelaine, G. 1980. Onzième inventaire et analyse des fluctuations des populations d'oiseaux marins dans les refuges de la Côte Nord du Golfe Saint-Laurent. Canadian Field-Naturalist 94: 34-42.

Chapdelaine, G. 1995. Fourteenth census of seabird populations in the sanctuaries of the North Shore of the Gulf of St. Lawrence, 1993. Canadian Field-Naturalist 109: 220-226.

Chapdelaine, G., and P. Brousseau. 1984. Douzième inventaire des populations d'oiseaux marins dans les refuges de la Côte-Nord du golfe du Saint-Laurent. Canadian FieldNaturalist 98: 178-183.

Chapdelaine, G., and P. Brousseau. 1991. Thirteenth census of seabird populations in the sanctuaries of the North Shore of the Gulf St. Lawrence, 1982-1988. Canadian Field-Naturalist 105: 60-66.

Chapdelaine, G., and P. Brousseau. 1996. Diet of Razorbill Alca torda chicks and breeding success in the St. Mary's Islands, Gulf of St. Lawrence, Québec, Canada, 1990-1992. Pages 27-37 in Studies of high-latitude seabirds. 4. Trophic relationships and energetics of endotherms in cold ocean systems. Edited by W. A. Montevecchi. Canadian Wildlife Service Occasional Paper 91. Ottawa.

Chapdelaine, G., A. W. Diamond, R. Elliot, and G. J. Robertson. 2001. Status and population trends of the Razorbill in eastern North America. Canadian Wildlife Service Occasional Paper 105. Ottawa.

Chapdelaine, G., and J.-F. Rail. 1997. Relationship between cod fishery activities and the population of herring gulls on the North Shore of the Gulf of St Lawrence, Québec, Canada. ICES Journal of Marine Science 54: 708-713.

Coues, E. 1862. Notes on the ornithology of Labrador. Proceedings of the Academy of Natural Sciences of Philadelphia (1861): 215-257.

Hewitt, O. H. 1950. Fifth census of non-passerine birds in the bird sanctuaries of the North Shore of the Gulf of St. Lawrence. Canadian Field-Naturalist 64: 73-76.

Lemieux, L. 1956. Seventh census of nonpasserine birds in the bird sanctuaries of the North Shore of the Gulf of St. Lawrence. Canadian Field-Naturalist 70: 183-185.

Lewis, H. F. 1925. The new bird sanctuaries in the Gulf of St. Lawrence. Canadian Field-Naturalist 39: 177-179.

Lewis, H. F. 1931. Five years' progress in the bird sanctuaries of the North Shore of the Gulf of St. Lawrence. Canadian Field-Naturalist 45: 73-78.

Lewis, H. F. 1937. A decade of progress in the bird sanctuaries of the North Shore of the Gulf of St. Lawrence. Canadian Field-Naturalist 51: 51-55.

Lewis, H. F. 1942. Fourth census of non-passerine birds in the bird sanctuaries of the North Shore of the Gulf of St. Lawrence. Canadian Field-Naturalist 56: 5-8.

Moisan, G. 1962. Eighth census of non-passerine birds in the bird sanctuaries of the North Shore of the Gulf of St. Lawrence. Canadian Field-Naturalist 76: 78-82.

Moisan, G., and R. W. Fyfe. 1967. Ninth census of nonpasserine birds in the sanctuaries of the North Shore of the Gulf of St. Lawrence. Canadian-Field-Naturalist 81: 67-70. 
Nettleship, D. N., and A. R. Lock. 1973. Tenth census of seabirds in the sanctuaries of the North Shore of the Gulf of St. Lawrence. Canadian Field-Naturalist 87: 395-402.

Rail, J.-F., and G. Chapdelaine. 2002. Quinzième inventaire des oiseaux marins dans les refuges de la Côte-Nord : techniques et résultats détaillés. Série de rapports techniques No. 392. Service canadien de la faune, région du Québec, Environnement Canada, Sainte-Foy, xvi + 307 pages.

Rail, J.-F., G. Chapdelaine, P. Brousseau, and J.-P. L. Savard. 1996. Utilisation des oiseaux marins comme bio- indicateurs de l'écosystème du Saint-Laurent. Série de rapports techniques No. 254. Service canadien de la faune, région du Québec, Environnement Canada, Sainte-Foy, ii +113 pages.

Tener, J. S. 1951. Sixth census of non-passerine birds in the bird sanctuaries of the North Shore of the Gulf of St. Lawrence. Canadian Field-Naturalist 65: 65-68.

Received 16 June 2003

Accepted 5 July 2004 